\title{
Analysis of Cropping Practices on Two Irrigated Perimeters of the Volta Blanche Basin with the Use of Shallow Groundwater
}

\author{
Angelbert Chabi Biaou1, Chaim Vivien Doto1*, Dial Niang1, Boubacar Barry ${ }^{2}$ \\ ${ }^{1}$ Institut International d'Ingénierie de l'Eau et de l'Environnement, Ouagadougou, Burkina Faso \\ ${ }^{2}$ International Water Management Institute, Colombo, Sri Lanka \\ Email: *vivien.doto@2ie-edu.org
}

How to cite this paper: Biaou, A.C., Doto, C.V., Niang, D. and Barry, B. (2020) Analysis of Cropping Practices on Two Irrigated Perimeters of the Volta Blanche Basin with the Use of Shallow Groundwater. Journal of Water Resource and Protection, 12, 975-984. https://doi.org/10.4236/jwarp.2020.1211058

Received: September 5, 2020

Accepted: November 27, 2020

Published: November 30, 2020

Copyright $\odot 2020$ by author(s) and Scientific Research Publishing Inc. This work is licensed under the Creative Commons Attribution International License (CC BY 4.0).

http://creativecommons.org/licenses/by/4.0/

\begin{abstract}
This study aims to analyze the development of small-scale irrigation using shallow groundwater in Nahouri province (south-central Burkina Faso). The methodological approach adopted was essentially based firstly on semi-structured surveys with producers who have adopted sump technology and the monitoring of groundwater level using the installed piezometers and secondly on geophysical prospection. Results obtained show that market gardening is mainly a family activity practiced on plots of 0.20 ha with a predominance of pepper cultivation occupying about $75 \%$ of cultivated areas. It was also highlighted that this agricultural activity faces several constraints that delay its development. These include: lack of water, land insecurity, small and fragmented farms and difficulty in selling products when they are put on local markets at the very same time as significant price drops. This problem is accentuated by the perishable nature of these market garden products. Despite these limiting factors, there is some satisfaction considering the income earned by farmers, most of whom are able to meet their primary needs. This work made it possible to conclude that even in zones which are not sedimentary formations, it is possible to mobilize groundwater, at a reasonable depth for agricultural purposes, without much effort to practice additional irrigation, knowing that evaporation carries harm to the use of dams.
\end{abstract}

\section{Keywords}

Small Irrigation, Shallow Groundwater, Small Sumps, Gardening, Burkina Faso

\section{Introduction}

Burkina Faso is an arid country with an unfavorable geology with more than $2 / 3$ 
of the formations which are more or less fractured basement formations, to which are added the particularly unfavorable climatic conditions. In these conditions, Burkina Faso has developed new farming practices over the past few decades to improve its agricultural production. Indeed, since the 1970s, water control strategies have been developed to improve agricultural productivity. Several types of development were then created, including the development of large plains and the construction of many small earth dams and associated perimeters [1] [2] [3]. However, the results to date remain mixed, with insufficiently developed infrastructures whose management is largely deficient, and this agriculture remains dependent on more than $75 \%$ of rain-fed production subject to many constraints, among which can be mentioned:

- climate hazards: trend towards aridification of climate in the North, decrease in the plant growth period from 20 to 30 days and displacement of isohyets by $100 \mathrm{~mm}$ towards the South compared to the 1960s, rainfall characterized by strong inter-annual and spatio-temporal irregularities;

- soils that are generally shallow, with surface crusts that promote runoff, low water retention capacity and low organic matter content;

- water resources whose main problem lies in the geological nature of rocks (crystalline rocks that are not capable of storing thick, continuous and productive aquifers) providing low flows and resulting in the failure to meet

large punctual needs, such as needs of large-scale irrigation [4].

In such a situation, irrigation is considered as one of the solutions to improve the performance of this agriculture. This is the context within which farmers in Nahouri province resorted largely to irrigation for crop management. Indeed, the scarcity of water in this region, which has been going on for several years, has forced farmers to use groundwater more and more. This practice has increased further over the past ten years with the use of shallow hole water for market gardening. Unfortunately, this approach is not without consequences given that water resources are very limited in the area.

This research, part of a program entitled called Shallow Ground Water Irrigation aims to explore the techniques and expansion of shallow water mobilization by sumps and to assess the impact of this practice on agricultural production.

\section{Material and Methods}

\subsection{Study Area}

This study was conducted in the Nahouri province located in southern Burkina Faso, $150 \mathrm{~km}$ from Ouagadougou (Figure 1). The study was mainly carried out on two small irrigated perimeters located near the city of Po, a place characterized by a southern Sudanese climate and strong evapotranspiration. The rainy season, which runs from April to October, is characterized by a strong spatio-temporal irregularity with an inter-annual average of around $964 \mathrm{~mm}$ (period 1980-2008). The potential monthly reference evaporation rate is $169 \mathrm{~mm}$ for April (maximum value in the year) and $112 \mathrm{~mm}$ for July (minimum value). 


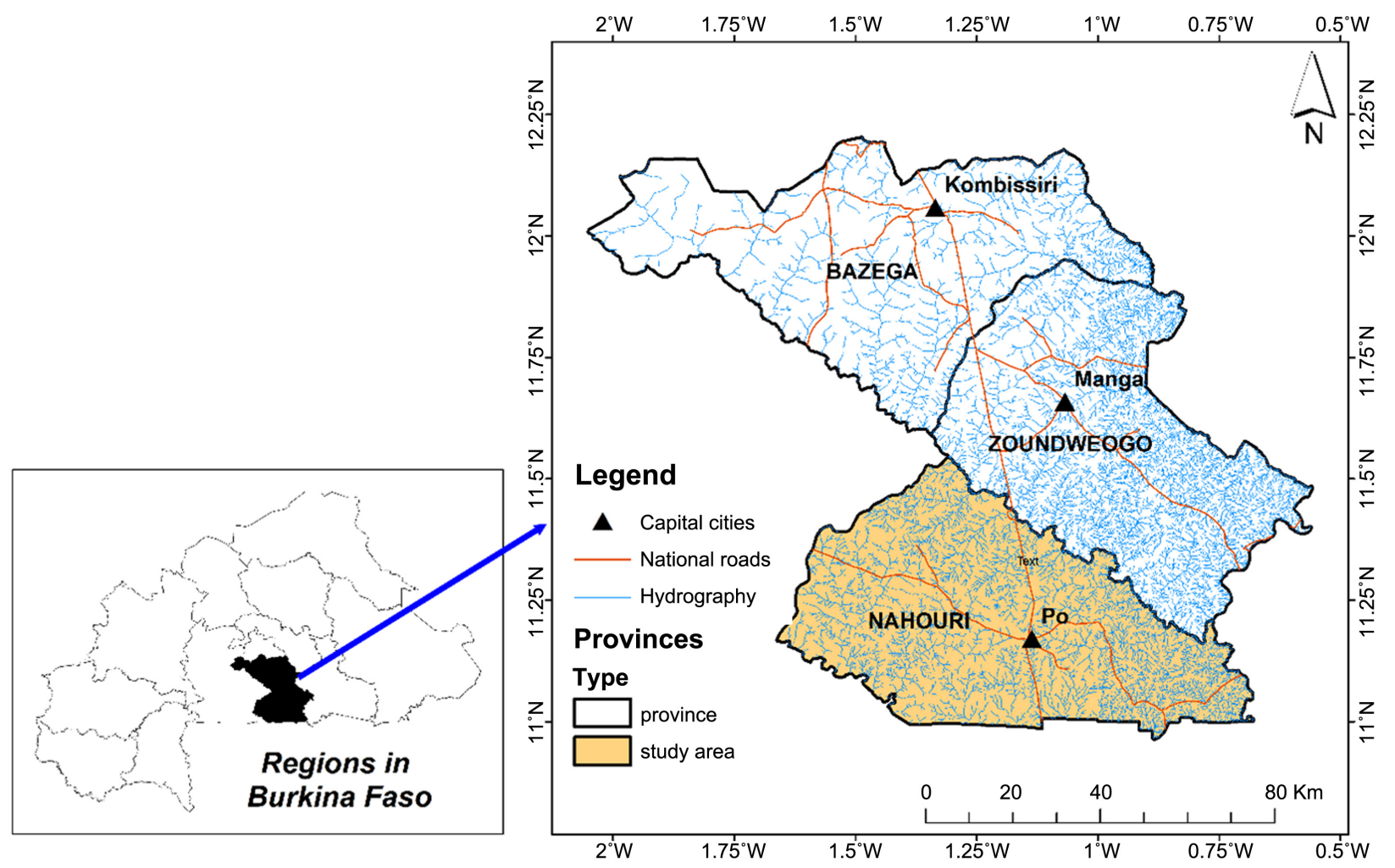

Figure 1. Location of the study area. Source: National Geographic Map, BNDT, 2020.

Soils are divided into 5 groups (crude mineral soils; poorly developed soils; browned soils; sesquioxide soils of iron and/or manganese and hydromorphic soils). Tambolo (located about ten kilometers from the Ghanaian border on National Road No. 5) and Kassambouga 2 (located downstream of the Po dam on the Tiébélé road) are the two places that were selected for this study. Each study site is equipped with several shallow wells dug by the operators, a class A evaporation pan, 2 piezometers and a direct reading rain gauge.

\subsection{Methodological Approach}

The methodological approach adopted was based firstly on field surveys and secondly on geophysical approach using the electrical method (drag, survey and tomography).

About the survey, thirty farmers were chosen through the diversity of the type of farms but also through voluntary work and availability. The questionnaire administered aimed to describe the overall functioning of the agricultural holding, in particular, to assess the farmer's labor resources and strategies. The main topics covered were:

- the holding cadastral survey and the status of the land;

- access to water;

- main speculations;

- cultural practices;

- the product marketing channel. 
Regarding the geophysical prospection method, it is a method that consists of sending a current through two electrodes A and B into the subsoil and measuring the difference in potentials generated by the signal. This difference in potentials makes it possible to deduce the apparent resistivity exhibited by the underlying rocks, resistance which makes it possible to deduce the presence of water in the explored matrix. The results presented for the tomography come from a Syscal R1 Plus, having 72 electrodes spaced $5 \mathrm{~m}$ apart through 4 coils of 18 electrodes placed on either side of the Syscal, which corresponds to an investigation distance of $355 \mathrm{~m}$ for a simple tomography. Half of the device can be deployed as many times as desired (move the device to the other end, in the direction of the investigation and move the device before the device downstream of the new location device) in order to cross-check.

Figure 2 and Figure 3 show measuring instruments.

In each of the villages in the study area, the producers are organized into a cooperative and practice the same crops, on a fairly homogeneous perimeter, allowing the practice of supplemental irrigation with "shallow ground water". This

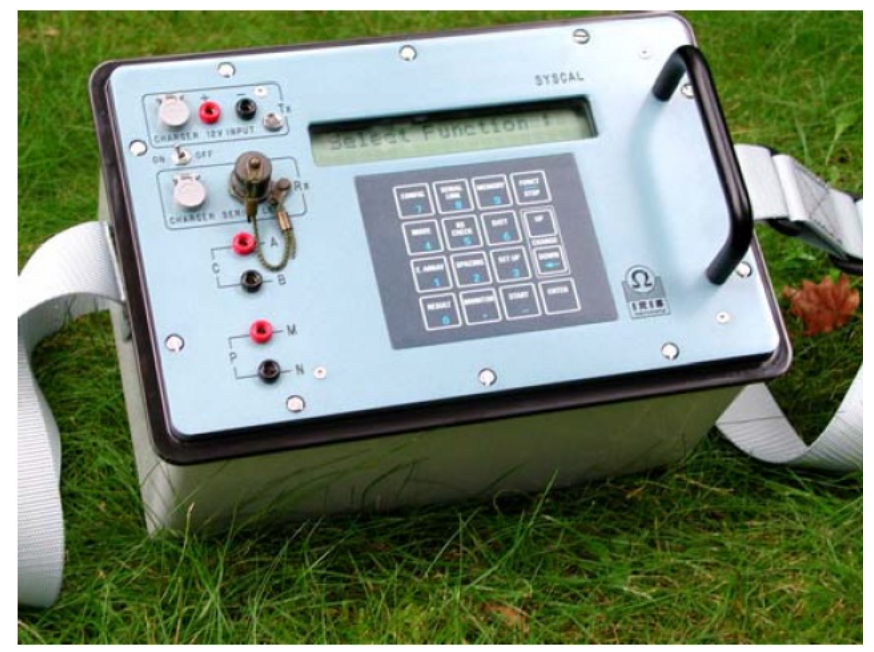

Figure 2. Syscal R1 Plus, device for making resistivity measurements of formations.

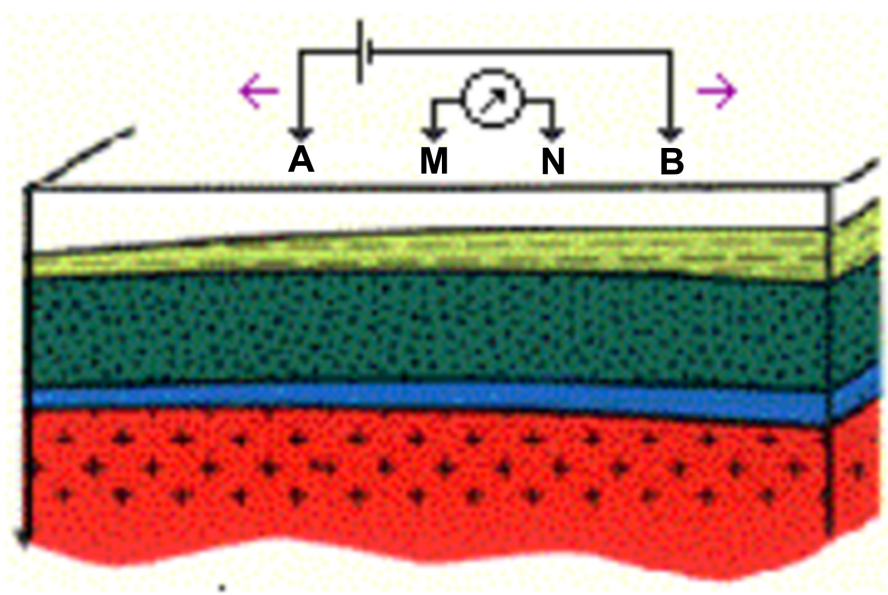

Figure 3. Measuring device, with the Syscal device located in the middle of MN and AB. 
simplified the sampling. While doing the geophysical study, we could do field surveys with these producers. Given this homogeneity, we did not need to apply a sample process, such as Gumbel, or Student.

Data of the surveys were analyzed and interpreted with the Excel spreadsheet. As for the geophysical data, they were interpreted and analyzed by the Res2Dinv software supplied with the syscal.

\section{Results and Discussion}

\subsection{Holding Cadastral Survey and Status of the Land}

At both sites, the developed plots are small family or individual farms not exceeding 0.25 hectares with essentially private management in the sense that each farmer manages the agricultural development of his plot completely independently. The land used comes from a family legacy and/or a transfer of rights of use from the head of land. Indeed, according to the customary rules of the region, land is considered by indigenous peoples as a sacred patrimony inherited from their ancestors that cannot be attributed or transferred to relatives [5]. It is in fact a usufructuary right, depending on membership of a group in the community or a lineage. This approach is specific insofar as Burkina Faso has a land law based on a principle and an exception. The principle is the State ownership which establishes that all lands located within the limits of the national territory constitute the national land domain. Private property is the exception, which stipulates that certain land in the national land domain may be transferred as private property to natural or legal persons, under the conditions laid down by law. Current analyses of land issue show the complexity of the matter and raise questions about the ability of new approaches to reach the heart of dysfunctions in land management systems. Indeed, the customary land tenure system in Nahouri province hinders the development of irrigation in that farmers refuse to invest in the long term for fear of having their land confiscated.

\subsection{Access to Water}

Geophysical prospecting by electric tomography shows that groundwater table is within reach (Figure 4) and can extend over a thickness of 20 to $30 \mathrm{~m}$. However, the surface layer, which is generally sandy, has local outcrops of healthy rock, making it difficult to sink wells and sumps. Water is mobilized at the 2 study sites by digging wells and sumps whose depth never exceeds 10 meters and water is extracted using containers (watering cans or plastic cans). On Tambolo site, the groundwater is much deeper than at Kassambouga 2 where the existence of a roadblock upstream favors outcropping of the healthy rock. On these sites, water management is different as wells and sumps in Tambao are individual while in Kassambouga 2 they belong to all the operators. Use of groundwater does not meet the high demand for water for market gardening. Indeed, on both sites, it is only possible to practice one campaign. The reasons are largely due to surface network constraints, climate hazards and low groundwater recharge. 

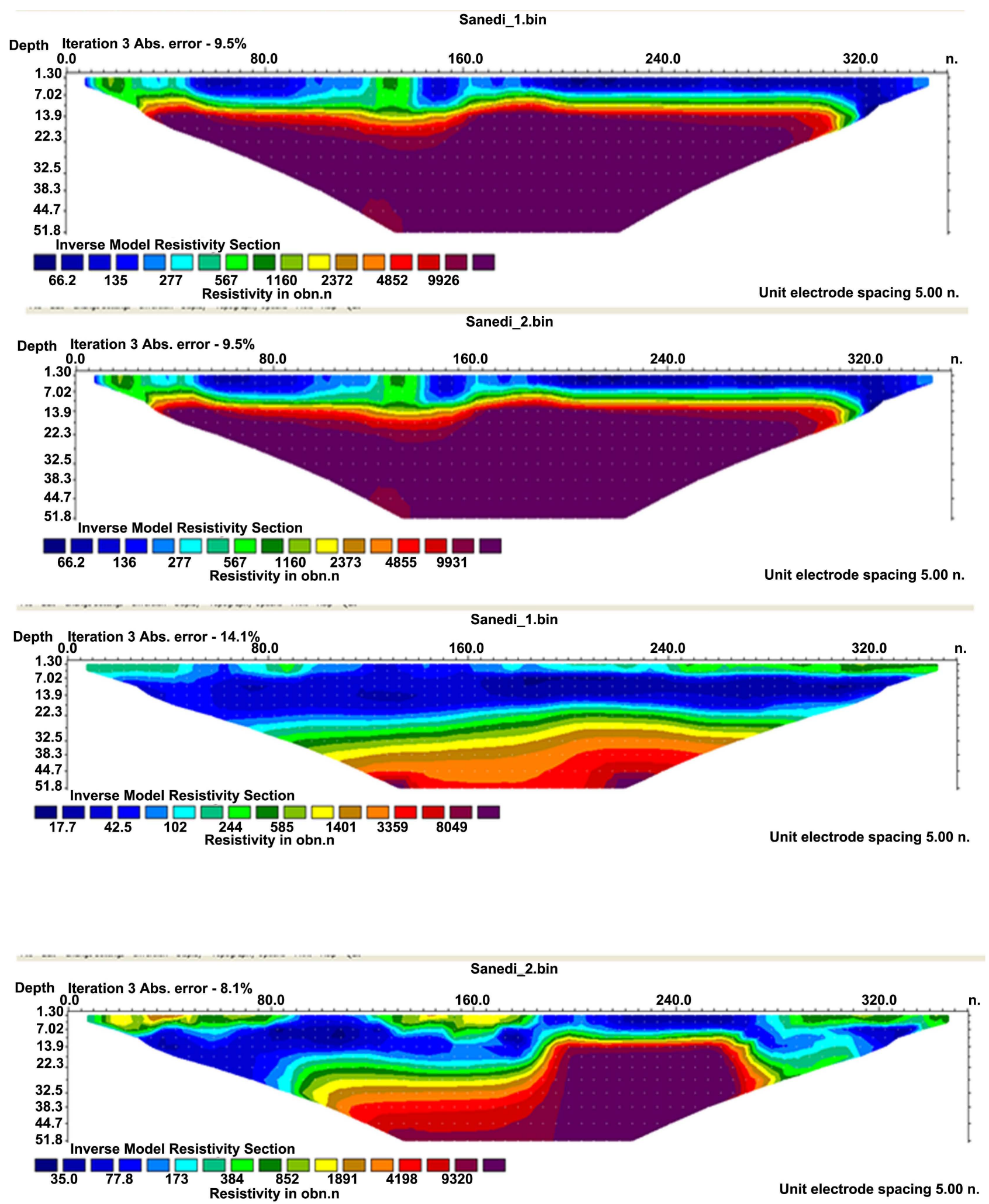

Figure 4. Tomographies made on both study sites (in top at Kassambouga 2 site and in bottom at Tambolo site).

The irrigation system set up is that of dewatering, transport and application of container irrigation. Water is taken from the sump, transported to the plot and 
applied using 15-litre watering cans. Farmers water twice a day (from 7am to $11 \mathrm{am}$ and from $3 \mathrm{pm}$ to $5 \mathrm{pm}$ ) throughout the week. This daily watering time may vary from one farmer to another depending on the size of the plot.

\subsection{Main Crops}

Market gardening is mainly practiced in dry season, from the end of September to May, a period during which farmers are more available. Speculations are chosen according to the length of the crop cycle and labor and input requirements. On the one hand, there are long cycle crops composed mainly of fruit vegetables (tomatoes, cucumbers, eggplant, peppers, onion, etc.), and on the other hand, short cycle vegetables are composed mainly of "leafy vegetables" (salads, cabbage, etc.). In the study area, dominant agricultural crops are onion, tomato, chili and other vegetables for family food and local trade (eggplant, lettuce, cabbage, okra, pepper, and cucumber) and some fruit trees. Methods of crop management are based on peasant know-how. Due to its importance (not quantifiable due to lack of data) in eating habits and the interesting income it generates, chili is found in almost all vegetable farms. It represents more than $75 \%$ of the cultivated areas (Figure 5).

\subsection{Cropping Practices}

Market gardening characterization surveys carried out during the period 2008-2011 allowed a better understanding of the different approaches to market gardening in Nahouri. Seeding is carried out in an open ground nursery and plants are pulled out 20 to 30 days later, then transplanted directly into the field (except for chili which is an annual plant). The first plantings start at the earliest in October when rainfall decreases and the soil moisture allows plowing. The last cultivation ends in May-June, which marks the beginning of the rainy season. After the last harvest, chili plants are not uprooted and remain in place until the next off-season crop. Table 1 and Table 2 present respectively the quantities of

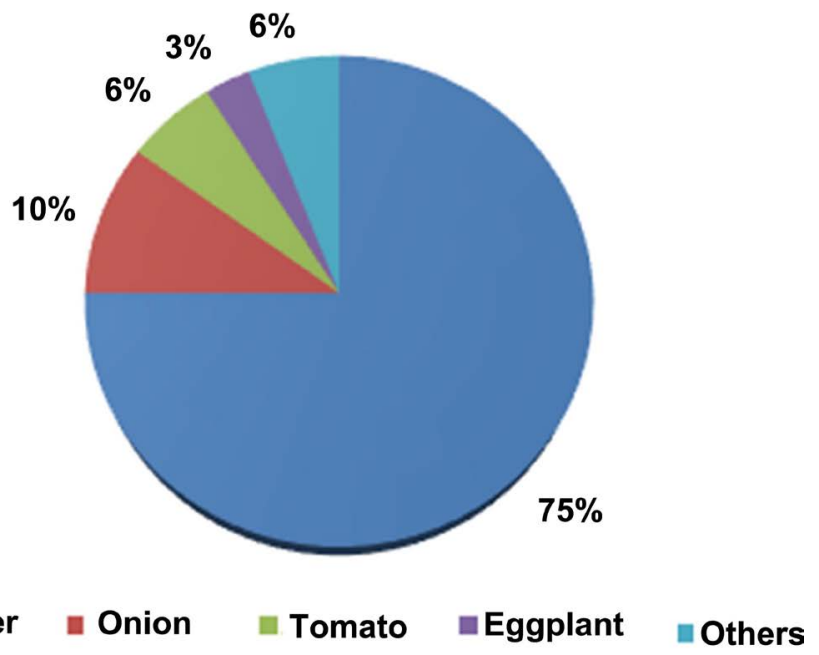

Figure 5. Distribution of market gardening systems on both study sites. 
Table 1. Volume of water supplied per hectare for tomato cultivation.

\begin{tabular}{cccc}
\hline Stage & 1 to 30th day & 31 to 90 th day & 31 to 120th day \\
\hline $\begin{array}{c}\text { Daily irrigation } \\
15.30 \mathrm{~m}^{2} \text { board }\end{array}$ & 4 watering cans $\times 15 \mathrm{~L}$ & 6 watering cans $\times 15 \mathrm{~L}$ & 4 watering cans $\times 15 \mathrm{~L}$ \\
Irrigation $\left(\mathrm{m}^{3} / \mathrm{ha} /\right.$ day $)$ & 39.2 & 58.8 & 39.2 \\
Irrigation $\left(\mathrm{m}^{3} / \mathrm{ha} / \mathrm{phase}\right)$ & 1176.5 & 3528 & 1176.5 \\
Total irrigation $\left(\mathrm{m}^{3} / \mathrm{ha}\right)$ & & $\mathbf{5 8 8 1}$ & \\
\hline
\end{tabular}

Table 2. Actual water requirements of tomatoes per hectare.

\begin{tabular}{ccccc}
\hline Stage & Vegetative & Flowering and Setting & Fruit filling and Ripeness & Harvest \\
\hline Number of days per phase & 25 & 25 & 20 & 50 \\
Crop coefficient $(\mathrm{Kc})$ & 0.3 & 0.6 & 0.9 & 0.8 \\
$\mathrm{ET}_{0}(\mathrm{~mm} /$ day $)$ & 5.7 & 6.0 & 6.5 & 6.5 \\
Irrigation $\left(\mathrm{m}^{3} / \mathrm{ha} /\right.$ day $)$ & 17.1 & 36 & 58.5 & 52 \\
Irrigation $\left(\mathrm{m}^{3} / \mathrm{ha} /\right.$ phase $)$ & 427.5 & 900 & 1170 & 2600 \\
Total irrigation $\left(\mathrm{m}^{3} / \mathrm{ha}\right)$ & & 5097.5 & & \\
\hline
\end{tabular}

water provided by farmers to eventually grow a tomato crop and the actual water requirements of the same plant.

Analysis of Table 1 and Table 2 shows that the quantity of water supplied by farmers is higher than the actual needs of tomatoes, which is paradoxical given that lack of water is the main constraint on agricultural production in this region. We also note insufficient soil fertility management given that application dates and quantities recommended by extension services are not respected. Fertilizer inputs (NPK and Urea) are variable depending on the financial availability of producers. This is one of the main factors limiting agricultural production because mineral fertilizer inputs are generally lower than recommended doses. Indeed, fertilizer inputs are variable and generally range from 100 to $150 \mathrm{~kg} / \mathrm{ha}$ of NPK and 50 to $100 \mathrm{~kg} / \mathrm{ha}$ of urea, while recommended rates are about 200 to $250 \mathrm{~kg} / \mathrm{ha}$ for NPK and $150 \mathrm{~kg} / \mathrm{ha}$ for urea [6]. For organic amendment, quantities applied are also low (10 to $15 \mathrm{t} / \mathrm{ha}$ ) compared to recommended doses (20 to $30 \mathrm{t} / \mathrm{ha}$ ). The quality of inputs (seeds, mineral fertilizers and phytosanitary products) commercialized on the market is often of poor quality [7]. This problem has been exacerbated by the liberalization of trade in inputs and the lack of control by public services. Also, the low use of organic manure can be attributed to the lack of small transport equipment (carts, wheelbarrows, shovels, rakes etc.). It will therefore be necessary to improve the supply of equipment for manufacture and transport of organic manure, provide support for seed production and the supply of good quality inputs to producers. This support includes the production of selected seeds, quality control of mineral fertilizers and seeds in well-equipped testing laboratories.

\subsection{Produce Distribution Channel}

The distribution channel for agricultural produce is characterized by a weak or- 
ganization. Production is sold informally because of the lack of farmers' organization. Indeed, each producer prefers to sell his crops himself and there are market bottlenecks because crops arrive on the market at the same time, and this often leads to clearance sale of these crops. In addition, this lack of organization often puts producers in a weak position with regard to resellers involved in the collection and marketing of agricultural produce, especially when it comes to perishable produce such as tomatoes. In the study area, crops are sold on local markets or at the farm gate, when traders, especially women, come to supply the markets of Pô, Guelwongo and Dakola. Chili is generally sold in Ghana where it is easier to sell and prices are very attractive. However, the profit margin of Burkinabe producers is not too high because of the currency difference. They are obliged either to make the change (always to their disadvantage), or to buy equipment on site that they will try to sell once back home.

In short, the agricultural products marketing circuit includes wholesalers who come to obtain supplies directly from the field and retailers who are served on local or border markets either by wholesalers or by producers who transport their agricultural products to these markets.

\section{Conclusions}

This current work on Nahouri province is part of a research program between several international institutions. The team aimed to explore the techniques and expansion of shallow water mobilization by sumps and wells around surface water reservoirs in the Volta Blanche sub-basin straddling Burkina Faso and Ghana, and to assess the impact of this practice on improving production and life quality of the populations who use it.

It seems, in view of these results, that a number of constraints are hindering the development of market gardening in Nahouri despite the substantial income earned by farmers. The main shortcomings are the scarcity of water resources, land constraints, poor organization of producers on the sites, lack of control of efficient farming techniques and lack of knowledge of good farming practices (water requirements of crops and date of application and recommended doses of uncontrolled fertilizers). Farmers also face problems with the supply of agricultural inputs and equipment. Land insecurity is particularly evident in the succession and number of crops over the season, and by the impossibility for a certain category of producers to cultivate over consecutive several years on the same plot and therefore to manage previous crops, which can influence the parasite risk in the field. Analysis of the influence of environmental conditions on yield components remains incomplete (e.g., relationships between population health conditions and treatments). Nevertheless, the knowledge we have produced makes it possible in the short term to consider ways of improving the management of market gardening in the region to increase production and reduce work times. They mainly involve water supply (with a reduction in inputs) and management of vegetation and health protection, which remains an uncontrolled 
agricultural operation.

\section{Acknowledgements}

This research was funded by the International Water Management Institute which we thank. Our thanks also go to the producers of Nahouri province who contributed to the success of this study.

\section{Conflicts of Interest}

The authors declare no conflicts of interest regarding the publication of this paper.

\section{References}

[1] Aouba, H. (1993) L'irrigation au Burkina Faso: Historique, situation, perspectives. In: Quel environnement pour le développement de Pirrigation au Burkina Faso. Actes séminaire-atelier, 1-3 février 1993, Ouagadougou, Burkina Faso, 29-48.

[2] Nyssen, J., Govaerts, B., Araya, T., Cornelis, W.M., Bauer, H., Haile, M., Sayre, K. and Deckers, J. (2011) The Use of the Marasha Ard Plough for Conservation Agriculture in Northern Ethiopia. Agronomy for Sustainable Development, 31, 287-297. https://doi.org/10.1051/agro/2010014

[3] Biazin, B., Sterk, G., Temesgen, M., Abdulkedir, A. and Stroosnijder, L. (2012) Rainwater Harvesting and Management in Rainfed Agricultural Systems in Sub-Saharan Africa-A Review. Physics and Chemistry of the Earth, 47-48, 139-151. https://doi.org/10.1016/j.pce.2011.08.015

[4] MAHRH (2001) Etat des lieux des ressources en eau du Burkina Faso et de leur cadre de gestion. MAHRH, Ouagadougou, $252 \mathrm{p}$.

[5] Cotula, L. (2006) Concepts clés et tendances des politiques et législations, in Droits fonciers et accès à l'eau au Sahel: Défis et perspectives pour l'agriculture et l'élevage. International Institute for Environnent and Development (IIED). dossier, No. 139.

[6] MAHRH (2005) Programme de gestion des sols pour un développement durable de l'agriculture irriguée au Burkina Faso. MAHRH, Ouagadougou, 56 p.

[7] Bassolé, D. and Ouédraogo, L. (2007) Problématique de l'utilisation des produits phytosanitaires en conservation des denrées alimentaires et en maraîchage urbain et péri urbain au Burkina Faso: Cas de Bobo Dioulasso, Ouahigouya et Ouagadougou. APIPAC, IFDC, $51 \mathrm{p}$. 